\title{
Public Services at the Samsat Office of Brebes District (Study of Motorized Vehicle Taxpayers)
}

\author{
Simpati Nisa Wijaya ${ }^{1}$, Siti Rodhiyah Dwi Istinah² and Rachmat Bowo \\ Suharto ${ }^{3}$
}

Abstract. This study aims to determine the problems found in the Samsat Office regarding the maintenance of motor vehicle taxpayers.

The method of approach used in this study uses the Sociological Juridical Approach Method, data using Descriptive specifications, data consisting of primary data and secondary data, analyzed with Quantitative, The data used are primary and secondary, primary data in the form of interviews, secondary data in the form of bibliography and laws. How to obtain data by interviewing and conducting research to SAMSAT Brebes Regency.

Supporting factors and inhibiting factors Motor Vehicle Taxpayer Services have used the Online system that makes it easy for the public in the Extension of Motor Vehicle Taxpayer, Need to improve service excellence to the community regarding service obligation to pay vehicle tax and implement the SAMSAT program routinely, especially in places far from reach or in remote villages, this embodies the commitment to provide the best service for the community Keywords : Public Services; Taxpayers; Motorized Vehicles.

\section{Introduction}

Public service to the community is one of the important tasks or functions of the government in carrying out its governmental tasks. The government must be able to develop the ability and creativity to provide services that meet the needs of the community because the quality of public services will always improve both in terms of quantity in line with the increasing number of products ${ }^{4}$.

One government agency that has a duty in public service is the government agency in vehicle tax services. According to the Minister of Home Affairs Regulation No. 23 of 2011 concerning motor vehicle taxpayers. In terms of taking care of the completeness and ownership documents regarding government motor vehicles, the SAMSAT (OneRoofed One-stop Administration System) office is an administrative system established to facilitate and accelerate the service of the interests of the community whose activities are carried out in one building. SAMSAT is an integrated collaboration system between the National Police, the Provincial Revenue Service, and PT Jasa Raharja (Persero).

In Brebes an office with SAMSAT has also been established, the mobility of motorized vehicles in Brebes is quite large. Especially with the existence of a motor vehicle loan disbursement policy that makes it easy for people to do motor vehicle loans, so that

\footnotetext{
1 Student of Master of Law, Sultan Agung Islamic University (UNISSULA), Semarang, email simpatiwijaya@gmail.com

${ }^{2}$ Lecturer of Master of Law, Sultan Agung Islamic University (UNISSULA), Semarang

${ }^{3}$ Lecturer of Master of Law, Sultan Agung Islamic University (UNISSULA), Semarang

${ }^{4}$ Lukman Sampara, 2000, Manajemen Kualitas Pelayanan Publik, Jakarta: STIA LAN Press, p. 57.
} 
more and more people are taking motorcycles on credit without thinking about installments and interest every month.

As the number of motor vehicle owners increases each year, the SAMSAT office has difficulty in serving the public in the service of vehicle taxpayers.

Another problem is about infrastructure in SAMSAT. Regarding complaints from the public about the facilities and infrastructure at the SAMSAT Brebes office, it has also not been provided to the maximum extent in supporting the service process. For example AC inside the SAMSAT office room that is not functioning properly, only a portion of the $A C$ is functioning in the room while the mobility of people in the SAMSAT office who wants to pay vehicle tax is very much so that it creates a hot air when queuing inside the room is very pronounced.

When there are complaints from the public about the service process related to unreasonable service costs, the affected SAMSAT is causing negative public perceptions about the management of taxes, because people more often choose to remain silent and pay to brokers rather than report irregularities regarding services to SAMSAT. Therefore, SAMSAT had difficulty in following up the deviation.

The existence of activities or public policy activities is not just born but through a process of rational thought and reasoning that is mature and requires a long time, the apparatus as the main actor of public service needs to recognize and understand the identity of public organizations properly has the ability to display the work of the SAMSAT office in Brebes Regency in order to provide the best service to the community especially the people in Brebes Regency.

In order to improve service quality and solve problems that often occur in public organizations, it requires a service innovation to be better. A public service is said to be of quality if the service is able to provide satisfaction to the people who receive services can be concluded ${ }^{5}$. From the description above, it can be seen that motor vehicle services in the SAMSAT Brebes Office show the low quality of motor vehicle tax services so that people's expectations in fulfilling their rights as taxpayers have not been reached optimally.

This encourages the Brebes government to improve the quality of services that are humanist, fast, precise, accurate, transparent, professional and accountable as well as uniforms and standards throughout Indonesia as the public service bureaucracy reforms. There needs to be socialization to the public about the importance of taxpayer compliance, the importance of socialization to the public to understand and understand the benefits of paying taxes.

Based on the background description described above, the following problems are formulated: How is public service for motorized taxpayers in the SAMSAT office in Brebes Regency? And What are the supporting and inhibiting factors in vehicle tax services at the SAMSAT office in Brebes Regency?

\section{Research Methods}

\footnotetext{
${ }^{5}$ Patricia Patton, 1998, EQ: Pelayanan sepnuh hati, terjermahan hermes, Jakarta: Pustaka Delapatra, p. 1.
} 
The method of approach used in this research is the sociological juridical approach method, which is research based on normative legal science (legislation), but not reviewing the norm system but observing how the reactions and interactions occur when the norm system works in society. ${ }^{6}$

The research specification is analytical descriptive, which provides a clear, detailed and systematic picture. The data used include primary data and secondary data obtained through field studies and literature studies. The data analysis method uses qualitative analysis.

\section{Results And Discussion}

\subsection{Public Services For Motorized Taxpayers At The SAMSAT Office In Brebes Regency}

Public service is the fulfillment of the desires and needs of the community by the state administrators or the provision of services to the public. The state was established by the public, of course with the aim of improving the welfare of the community, essentially the state in government must be able to meet the needs of the community. Theoretically, the purpose of public service is basically to satisfy the community to achieve satisfaction that demanded the quality of excellent service that is reflected in: ${ }^{7}$

- Transparency is a service that is open, easy and can be accessed by all parties who need it and is provided adequately and easily understood.

- Aquatics is a service that can be accounted for in accordance with statutory provisions.

- Conditional namely services that are in accordance with the conditions and capabilities of service providers and recipients while adhering to the principle of efficiency and effectiveness.

- Participatory services, which can encourage community participation in the delivery of public services by taking into account the aspirations, needs and expectations of the community.

- Equality of rights namely service that does not discriminate seen from any aspect, especially ethnicity, race, religion, class, social status. (Sampara lukmana, management of service quality,

- Balance of rights and obligations, namely services that consider aspects of justice between the buyer and recipient of public services.

Based on the notion of quality states that basically the quality refers to the basic understanding:

- Quality consists of a number of product features, both direct features and attractive features that meet customer desires and provide satisfaction with the use of the product.

- Quality consists of everything that is free from deficiencies or damage ${ }^{8}$.

\footnotetext{
${ }^{6}$ Mukti Fajar ND and Yulianto Achmad, 2012, Dualisme Penelitian Hukum Normatif dan Empiris, Yogyakarta: Student Library, p.47.

${ }^{7}$ Patricia Patton, 1998, EQ: Pelayanan sepnuh hati, terjermahan hermes, Jakarta: Pustaka Delapatra, p. 1.

${ }^{8}$ Jakarta: STIA LAN Press, 2000
} 
In order to provide quality services, of course both qualities must be fulfilled. Government in general cannot meet these two qualities so that public services are less than satisfactory. Quality of service is closely related to systematic and comprehensive service, better known as the concept of excellent service. Service personnel should understand the prime service variables as contained in the public sector service sector behavioral agenda, namely:

- The government is tasked with serving.

- Community served by the government.

- Wisdom is used as the basis of public service.

- Sophisticated equipment or service facilities.

- Resources available to be formulated in the form of service activities.

- Quality of service that satisfies the community in accordance with the standards and principles of community service.

- Management and leadership and community service organizations.

The behavior of officials involved in community service, whether each has carried out their functions ${ }^{9}$

Excellent service in the public sector as above can be implemented if the service apparatus successfully makes customer satisfaction as its main goal. So that customer satisfaction is the main goal is met, service officials are required to know with certainty who the customer is. The paradigm of public service in Indonesia must be changed. Various phenomena of public services must be improved, so that public services can be optimized. The real value in wholehearted service lies in the seriousness of 4 (four) attitudes:

- Passionate(passion). This results in great enthusiasm for work, for yourself, for others. The enthusiasm in the attention that is brought to the service wholeheartedly will distinguish how to kick yourself and work from behavior and how to provide services to the community. They know whether we respect them or not.

- Progressive (progressive). Namely the creation of new and exciting ways to improve service and personal style.

- Proactive. Namely in order to actively involve our work. Many people just stay quiet and wait to be told to do something if needed. To achieve better service quality, proper initiatives are needed.

- Positive(positive). Namely smile is a universal sign language that is understood by all people on this earth. Being positive is very interesting.

As for the strategic definition stated that quality is anything that is able to meet the desires or needs of customers, basically the quality refers to the basic understanding:

- Quality consists of a number of product features, both direct features, as well as attractive features that meet customer desires and provide satisfaction with the use of the product.

- Quality consists of everything that is free from deficiencies or damage.

\footnotetext{
${ }^{9}$ Patricia Patton, 1998, EQ: Pelayanan sepnuh hati, terjermahan hermes, Jakarta: Pustaka Delapatra, p. 1.
} 


\subsection{Application for Motor Vehicle Taxpayers at the SAMSAT office in Brebes Regency.}

Public Services on Handling Motor Vehicle Taxpayers at the SAMSAT Office. There are also procedures determined by SAMSAT:

- The applicant comes to the SAMSAT office and completes the requirements that will be used to extend the motor vehicle tax, in this case it takes 5 minutes to photocopy the completeness data in the form of KTP and STNK then complete with a red stop map.

- The applicant if he has completed the requirements then goes to the counter to submit the file and get the number of the delivery person, in this case it takes 10 minutes.

- The applicant waits for a call to pay the motor vehicle tax bill to the cashier, in this case it takes 5 minutes.

- After paying the applicant's bill declared in full then the applicant is waiting to be called to collect the extended vehicle registration.

- If the applicant has obtained a new STNK then checks again whether it is suitable or not.

Motor Vehicle Taxpayer service procedures at the SAMSAT office in Brebes Regency as referred to in the Minister of Domestic Affairs Regulation Number 23 of 2011 concerning Motor Vehicle Taxpayers. In the SAMSAT Brebes office there is a taxpayer service that is listed in and the governor of Central Java Governor Number 21 of 2011 Regarding the Implementation Guidelines for the Central Java Provincial Regulation, Further provisions regarding the procedure for taxation are regulated in Law number 28 of 2007 concerning general provisions and procedures taxation.

Table 1. Recapitulation of targets and receipt of original regional revenue which is managed directly by UPPD Brebes district for the 2017 budget year

\begin{tabular}{|c|c|c|c|c|c|}
\hline \multirow{2}{*}{ No } & \multirow{2}{*}{ SYNIS FKNEHIMAAN } & \multirow{2}{*}{ TARGXT } & \multirow{2}{*}{ PKNERIASAN } & \multirow{2}{*}{$\%$} & setisin \\
\hline & & & & & I.FBH / KUR N NG. \\
\hline 1 & 3 & 4 & 7 & s & 9 \\
\hline 1 & PAJAK DAERAII & $210.476 \times 90.000$ & $201.034,342,050$ & $951 \%$ & 944.547.950 \\
\hline 1 & PAJAK KENDARAAN BERMTOTOR & 52.860000 .000 & 9.853 .920 .500 & $109,79 \%$ & (x.73).32n.900) \\
\hline 2 & BEA BAL.IK NAMA KKNDARAAN ВERMOTOR & 120.551 .000 .000 & 102.302 .088 .900 & $84,86 \%$ & 12.251 .911 .100 \\
\hline 3 & PASAK PENGAMBL LN DAN WYMANGAATAN AF & $\$ 2.200 .6000$ & $7 k, 412.250$ & $124,71 \%$ & (15.5.2.250) \\
\hline 11 & AETHIBESI DAERAII ( KAYADA) & 150.508000 & 163.261 .500 & $108,95 \%$ & $(93.323 .500)$ \\
\hline 1 & HAGT HASH.SEWA IAIHAN & Genecono & 73.315 .500 & $122.19 \%$ & (13)313.50\% \\
\hline 2 & SWWA KEMAH DINAS & 6.000 .000 & 6.000 .000 & $100,000 \%$ & $\cdot$ \\
\hline 3 & SEWA GVDUNG /AULA & 2.020 .000 & $2 \times 00,000$ & $100,00 \%$ & - \\
\hline 4 & SKWA KANTIN/ FOTO COPY & 23.418 .000 & 23.418.0.0. & $100,00 \%$ & $\cdot$ \\
\hline 5 & KKW, LALAN PARKTR & $8 \times .240,000$ & 58.248 .000 & $100,01 \%$ & $(2.000)$ \\
\hline III & PENDUPATAN LUN-LALN & 000 & 2.46 .5797 .800 & & \\
\hline \multirow{3}{*}{$\begin{array}{l}y \\
10\end{array}$} & SANKSI PAMAK KENDAKAAN BEKMIOTOK & & 2.422 .846 .325 & & \\
\hline & SANKSI HE.A BALIK NAMA PKE & & 42.451 .475 & & \\
\hline & & 210.627 .428000 & $203,663.591 .350$ & $96,09 \%$ & $6.963 .926,650$ \\
\hline
\end{tabular}


Public service is the provision of services (serving) the needs of people or people who have interests or organizations in accordance with the basic rules and procedures that have been determined. ${ }^{10}$ Basically every human being needs service, even in the extreme it can be said that service cannot be separated from human life.

Society always demands quality public services from bureaucrats, even though the series is often not in line with expectations because empirically the public services that occur so far are characterized by convoluted, slow, expensive, tiring. This tendency occurs because the community is still positioned as a party serving not being served. ${ }^{11}$ Therefore, basically it is necessary to reform public services by returning and occupying servants and those who are served by true scholarship. The services that should be shown to the general public are sometimes turned into community services to the state, even though the state actually stands for the interests of the people who founded it. That is, bureaucrats really must provide the best service to the community. With the control of the public service community will be better because they will have a better commitment, more caring and more creative in solving problems. ${ }^{12}$ The services provided by bureaucrats are interpreted as obligations not rights because they are appointed by the government to serve the community, therefore a strong commitment must be built to serve so that services will be more responsive to community needs and can design more creative and more efficient service models. .

The Motor Vehicle Taxpayer Service at the SAMSAT UPPD Brebes Office has been running well, the SAMSAT Office has procedures for extending the motor vehicle tax, the public is willing to follow the existing regulations so that the implementation goes well and in an orderly manner.

Motor vehicle taxpayer services are safe and conducive so that it is very easy for people who will extend motorized vehicles, their services are very orderly according to applicable procedures. The environment of the Brebes Regency UPPD office is very comfortable and orderly for both employees and the public who are extending motor vehicle taxpayers.

\subsection{Supporting factors and inhibiting factors public services for motorized taxpayers at the SAMSAT office in Brebes Regency}

Lack of public compliance with the management of motor vehicle taxpayers is a major problem in motor vehicle taxpayers, so many violations committed by the public, especially regarding vehicle tax that have died or have been invalid even can be many years.

Based on the book published by the Head of SAMSAT UPPD, Brebes Regency. Efforts to Make Society aware of the importance of motor vehicle taxpayers:

- Disseminating information about Regional Taxes and handling receivables in the Brebes Regency Government. Another way to do the socialization through radio media, newspapers, electronic media or social media.

\footnotetext{
${ }^{10}$ Agung Kurniawan, 2005, Transformasi Pelayanan Publik, Yogyakarta: Renewal, p. 10.

${ }^{11}$ Lukman Sampara, 2000, Manajemen Kualitas Pelayanan Publik, Jakarta: STIA LAN Press, p. 120.

${ }^{12}$ Dunn, Wiliam N., 2000, Analisis Kebijakan Publik, Terjemah Samodra Wibawa, Yogyakarta: Gajahmada University Press, p.41.
} 
- In collaboration with the Indonesian National Police and the Central Java Provincial Civil Service Police Unit, a joint raid was conducted to increase the receipt of motor vehicle tax arrears. The aim is to conduct joint police raids, Satpol Pamong Peraja and raharja services with data collection that does not validate STNK and pay solid tax on time.

- Conduct data collection on motor vehicle tax arrears in the Brebes district together with the village head's association including the Brebes sub-district and the Bumi ayu sub-district, babinkamtibmas for the prohibited police station, youth Pancasila in the Banjarharjo sub-district and all agencies in the Brebes district to be aware of the motor vehicle tax mandatory.

- Adding the motorized vehicle tax service unit Samsat forbidding patents and traveling circumcisions makes it easier for the public to do the nearest motor vehicle taxpayer.

- Conducting good socialization in schools, government agencies and the community to raise awareness of paying motor vehicle tax on time.

- Holds a whitening or exemption from motor vehicle tax penalties at the end of the year as an effort by the public to comply with the motor vehicle taxpayers.

Request assistance from the Brebes district secretary to put in order a circular to the sub-district heads so that together with the village head to encourage payment of motor vehicle tax by the community and so that red plate motor vehicles do not have arrears in taxes.

\section{Closing}

\subsection{Conclusion}

- Public services about motor vehicle taxpayers at the SAMSAT office in Brebes Regency, we can take care of themselves without being represented by others, in the process of managing motor vehicle taxpayers there are already procedures for compulsory and compulsory motorized vehicles that are good and right so as to facilitate the public in motor vehicle taxpayers.

Based on Law Number 23 of 2011 concerning Motor Vehicle Taxpayers and Central Java Governor Regulation Number 21 of 2011 concerning Implementation of Regional Regulations of Central Java Province.

- Supporting factors and inhibiting factors for motor vehicle taxpayers namely pre facilities in motor vehicle taxpayers are sufficient so as to facilitate the public in motor vehicle taxpayers, a comfortable and safe environment around the SAMSAT Brebes Office that makes people feel comfortable when doing vehicle taxpayers motor vehicles, but lack of public awareness of motor vehicle taxpayers, this is the problem of the many violations of motor vehicle tax, so that not many people commit violations, one of which is the vehicle tax is up or dead for months or even years, socializing to the community, for those who do not understand IT, there is a mobile SAMSAT which makes it easy for the community to pay motor vehicle tax.

\subsection{Suggestion}


Conducting socialization to people who do not understand IT by way of SAMSAT activities going to every village or region that is far from reach so that the community is easier and more understanding about motor vehicle taxpayers.

To improve public services in Indonesia, it is not only expected that the internal role of the government apparatus but the role of the community must be expected. It is expected that the community will work more together to oversee the performance of bureaucratic employees and conduct or report any irregularities that occur in the implementation of public services to the community.

\section{References}

[1] Lukman Sampara, 2000, Manajemen Kualitas Pelayanan Publik, Jakarta: STIA LAN Press

[2] Mukti Fajar ND and Yulianto Achmad, 2012, Dualisme Penelitian Hukum Normatif dan Empiris, Yogyakarta: Student Library

[3] Agung Kurniawan, 2005, Transformasi Pelayanan Publik, Yogyakarta: Renewal

[4] Brotodiharjo R., Santoso, 2009, Pengantar ilmu Hukum Pajak, Bandung: PT Eresco

[5] Dunn, Wiliam N., 2000, Analisis Kebijakan Publik, Terjemah Samodra Wibawa,Yogyakarta: Gajahmada University Press

[6] Patricia Patton, 1998, EQ: Pelayanan sepnuh hati, terjermahan hermes, Jakarta: Pustaka Delapatra 